\title{
Gambaran Motivasi Orang Tua Menyekolahkan Anak \\ Pada Keluarga Petani Dijorong Damagadang Tanjung Sani Kabupaten Agam
}

\author{
Rheny Guchi Erniati \\ Pasca Sarjana Universitas Negeri Yogyakarta \\ erniati246@yahoo.co.id
}

\begin{abstract}
Abstrak
Penelitian ini dilatarbelakangi oleh berhasilnya pendidikan anak pada keluarga petani yang diduga berhubungan dengan motivasi orang tua dalam menyekolahkan anaknya. Tujuan penelitian ini adalah mendeksripsikan motivasi orang tua dalam menyekolahkan anak pada keluarga petani secara intrinsik dan ekstrinsik di Jorong Dama Gadang Nagari Tanjung Sani Kecamatan Tanjung Raya Kabupaten Agam. Jenis penelitian ini adalah penelitian deskriptif kuantitatif. Populasi dalam penelitian ini adalah seluruh warga masyarakat yang bekerja sebagai petani yang ada di Jorong Dama Gadang Nagari Tanjung Sani Kecamatan Tanjung Raya Kabupaten Agam sebanyak 130 orang, sedangkan sampel dalam penelitian ini adalah 33 orang yang diambil dengan menggunakan teknik random sampling. Teknik pengumpulan data menggunakan kuisioner, dan teknik analisis yang digunakan adalah persentase. Hasil penelitian ini menunjukkan bahwa motivasi orang tua dalam menyekolahkan anaknya secara intrinsik menunjukan angka tertinggi dan motivasi ekstrinsik juga tinggi.
\end{abstract}

Kata Kunci: Gambaran, Motivasi, Orang Tua

\section{An Overview of the Motivation of Parents in Sending Children In Farmer Families Dijorong Damagadang Tanjung Sani, Agam District}

\begin{abstract}
This research is motivated by the success of the education of children who were related to the family of the motivation of parents to send their children. The purpose of this study was description motivation of parents in educating children on the family farmers are intrinsically and extrinsically in Jorong Dama Gadang Nagari Tanjung Sani Kecamatan Tanjung Raya Kabupaten Agam. This research is descriptive quantitative research. The population in this study were all residents work as farmers in Jorong Dama Gadang Nagari Tanjung Sani Agam Kecamatan Tanjung Raya as many as 130 people, while the samples in this study were 33 people who were taken using a random sampling technique. Techniques of data collection in this research that uses questionnaires, analysis of the data used is the percentage. These results indicate that the motivation of parents send their children to be intrinsically showed the highest rate and ekstrinsic motivation is also seenhigh.
\end{abstract}

Keywords : Motivation, Parents, Picture 


\section{Diklus: Jurnal Pendidikan Luar Sekolah, 1(3), Maret 2019 - 45 Rheny Guchi Erniati}

\section{PENDAHULUAN}

Tujuan pendidikan adalah untuk meningkatkan kemampuan berfikir, perubahan sikap dan keterampilan. Untuk mencapai tujuan pendidikan itu di Indonesia dapat diperoleh melalui tiga jalur pendidikan sebagaimana dituangkan dalam UU No. 20 Tahun 2003 tentang sistem pendidikan nasional yaitu "jalur pendidikan terdiri atas pendidikan formal, non formal dan informal yang dapat saling melengkapi dan memperkaya." Dengan adanya tiga jalur pendidikan itu, sehingga memungkinkan bagi setiap warga negara Indonesia untuk memperoleh semua jenis pendidikan yang mereka inginkan.

Keluarga merupakan satuan unit sosial yang terdiri dari ayah, ibu, anak dan anggota keluarga lainnya, mempunyai arti yang sangat penting dalam pembentukan kepribadian anak dikemudian hari. Dalam lingkungan keluarga seseorang akan mempelajari sistem pengetahuan tentang norma-norma yang berlaku serta kedudukan dan peran yang diharapkan oleh masyarakat. Setiap kedudukan dan peran memberikan hak untuk mencari apa yang tidak boleh dilakukan serta kewajiban-kewajiban apa yang harus dilakukan sebagai warga dalam lingkungan sosial tertentu. Oleh karena itu penanaman nilai-nilai budaya dalam keluarga merupakan dasar utama bagi pembentukan pribadi anak.

Hubungan antara orang tua dan anak sangat penting artinya bagi perkembangan kepribadian anak, sebab orang tualah yang merupakan orang pertama yang dikenal oleh si anak. Melalui orang tualah anak mendapatkan kesankesan pertama tentang dunia luar. Bagi seorang bayi atau anak kecil, hubungan afeksi dengan orang tua merupakan faktor penentu, agar ia dapat "survive".

Penyelidikan

Renespitz, menunjukkan bahwa tanpa cinta kasih seorang bayi tidak dapat hidup terus; memperoleh cinta kasih merupakan kebutuhan dasar, seperti makan dan tidur. Orang tualah yang merupakan orang pertama yang membimbing tingkah laku anak. Terhadap tingkah laku anak mereka bereaksi dengan menerima, menyetujui, membenarkan atau menolak. Dengan demikian nilai terhadap tingkah laku berpengaruh dalam diri anak yang akan membentuk norma-norma sosial, normanorma susila dan norma-norma tentang apa yang baik dan buruk, apa yang boleh atau tidak boleh.

Penanaman nilai-nilai budaya pada anak bukan hanya sekedar merawat, mengawasi saja melainkan lebih dari itu yakni meliputi pendidikan, sopan santun, disiplin, tanggung jawab, mandiri, pengetahuan kebudayaan serta pendidikan yang diberikan orang tuanya. Pada dasarnya pendidikan dilakukan dalam keluarga, dalam masyarakat dan melalui sistem sekolah. Karena setiap manusia bermula kehidupannya dengan dilahirkan ibunya dalam lingkungan keluarganya, maka dapat dikatakan bahwa pendidikan di lingkungan keluarga menjadi landasan segenap usaha pendidikan sepanjang hidup manusia. Pendidikan di lingkungan keluarga sebagai landasan kehidupan bangsa.

Di Jorong Dama Gadang Nagari Tanjung Sani Kecamatan Tanjung Raya Kabupaten Agam ini, bukan hanya orang tua saja yang bekerja sebagai petani untuk memenuhi kebutuhan sehari-hari, melainkan anak-anak juga turut serta membantu orang tuanya.

Berdasarkan pengmatan dan informasi yang didapat dilapangan, untuk pendidikan anak-anak pada keluarga petani umumnya terbilang tinggi, tingginya kesadaran anak-anak itu sendiri dalam melaksanakan pembelajaran, selain itu motivasi yang diberikan orang tua kepada anak juga terbilang tinggi, orang tua sangat bersemangat untuk menekolakan anaknya, dan dorongan yang diberikan orang tua kepada anak baik dari dalam maupun luar diri orang tua untuk memberikan pendidikan secara formal kepada anak terbilang tinggi.

Maka dari fenomena di atas penulis tertarik untuk melakukan penelitian mengenai "Gambaran Motivasi Orang Tua 


\section{Diklus: Jurnal Pendidikan Luar Sekolah, 1(3), Maret 2019 - 46 Rheny Guchi Erniati}

dalam Menyekolahkan Anak pada Keluarga Petani di Jorong Dama Gadang Nagari Tanjung Sani Kecamatan Tanjung Raya Kabupaten Agam".

Pendidikan dalam arti sederhana sering diartikan sebagai usaha manusia untuk membina kepribadiannya sesuai dengan nilai di dalam masyarakat dan kebudayaan, selanjutnya pendidikan diartikan sebagai usaha yang dijalankan oleh seseorang atau kelompok orang lain agar menjadi dewasa atau mencapai tingkat hidup atau penghidupan yang lebih tinggi dalam arti mental (Hasbullah, 2001:1).

Pendidikan adalah usaha sadar untuk menyiapkan manusia peserta didik melalui kegiatan bimbingan, pengajaran, dan atau latihan bagi peranannya di masa yang akan datang. Dari beberapa pengertian yang diberikan para ahli tersebut, meskipun berbeda namun secara essensial terdapat kesatuan unsur atau faktor-faktor yang terdapat di dalamnya, yaitu bahwa pengertian pendidikan tersebut menunjukkan suatu proses bimbingan, tuntunan atau pimpinan yang di dalamnya mengandung unsur-unsur pendidik, anak didik, tujuan dan sebagainya.

Dapat disimpulkan bahwa pendidikan adalah usaha sadar dan terencana untuk mewujudkan suasana belajar yang berupa bimbingan dan pengarahan yang diberikan kepada anak dalam pertumbuhannya. Pendidikan juga merupakan pembentukan kepribadian dan juga kemampuan menuju dewasa.

Pendidikan informal atau pendidikan keluarga merupakan cakupan dari pendidikan luar sekolah, yang dapat diartikan sebagai pendidikan yang diperoleh seseorang di rumah dalam lingkungan keluarga. Pendidikan ini berlangsung tanpa organisasi, yaitu tanpa orang tertentu dan yang diangkat atau ditunjuk sebagai pendidik, tanpa suatu program yang harus diselesaikan dalam jangka waktu tertentu tanpa evaluasi yang formal berbentuk tujuan. Namun demikian pendidikan informal ini sangat penting bagi pembentukan pribadi seseorang.

Keluarga adalah wadah utama atau agen pensosialisasian budaya disetiap lapisan masyarakat. Proses sosialisasi sendiri adalah semua pola tindakan individu-individu yang menempati berbagai kedudukan dalam masyarakat yang dijumpai seseorang dalam kehidupannya sehari-hari sejak ia dilahirkan menjadikan pola-pola tindakan tersebut bagian dari kepribadiannya. (Koentjaraningrat, 1996:143).

Pendidikan anak adalah setiap usaha perlindungan dan bantuan kepada anak tertuju pada pendewasaan anak atau lebih tepat membantu anak agar cukup dalam melaksanakan tugas hidupnya sendiri dan pendidikan merupakan proses pembentukan kecakapan-kecakapan fundamental secara intelektual dan emosional kearah alam dan sesama manusia (Hasbullah, 2001:2). Menurut peneliti sendiri, pendidikan anak adalah usaha sadar yang dilakukan orang tua maupun masyarakat terhadap anak untuk mencapai suatu tujuan tertentu.

Kegiatan individu bukanlah merupakan suatu kegiatan yang terjadi secara begitu saja, tetapi ada faktor yang mendorongnya dan senantiasa ada tujuannya. Faktor yang mendorong individu untuk melakukan kegiatan disebut motif. Sedangkan tujuannya yaitu untuk memenuhi kebutuhan hidup dan mempertahankan eksistensinya.

Istilah motif erat sekali kaitannya dengan istilah motivasi. Seperti yang telah disebutkan bahwa motif merupakan dorongan atau kekuatan, sedangkan motivasi berarti hal-hal yang dapat menimbulkan kekuatan-kekuatan atau motif. Hal ini diungkapkan oleh Sadirman (2004:73), "bahwa motif dapat dikatakan sebagai daya penggerak dari dalam dan disubjek untuk melakukan aktivitasaktivitas tertentu demi mencapai suatu tujuan".

Dengan demikian dapat disimpulkan bahwa motif ini merupakan kesatuan tenaga dalam diri individu 


\section{Diklus: Jurnal Pendidikan Luar Sekolah, 1(3), Maret 2019 - 47 Rheny Guchi Erniati}

tersebut untuk melakukan kegiatan dalam rangka untuk mencapai tujuan, motif ini berkaitan dengan tingkah laku manusia yang mempunya motif. Tanpa motif orang tidak akan melakukan apa-apa. Motif bagi manusia sebagai dorongan, hasrat, keinginan yang menjadi penggerak yang berasal dari dalam manusia yang memberi arah kepada tingkah laku manusia.

Berawal dari pengertian kata motif itu, motivasi dapat diartikan sebagai pengaruh, suatu keadaan yang menimbulkan perilaku dengan kata lain motivasi ini merupakan penjelmaan akan hasratnya motif. Mengenai pengertian motivasi itu sendiri, berikut akan diuraikan beberapa pengertian yang dikemukakan oleh para ahli. Menurut Mc. Donal dalam Sardiman (2004:73) motivasi adalah perubahan energi dalam diri seseorang yang ditandai dengan munculnya "feeling" dan didahului dengan tanggapan terhadap tujuan. Sedangkan menurut Bohar Suharto: 18 mengatakan bahwa memotivasi adalah suatu proses dari suatu inisiatif untuk menggerakkan yang didasarkan atas pengembangan potensi (kesadaran) seseorang itu sendiri untuk melakukan sesuatu. Lebih lanjut Sardiman (2004:75) berpendapat bahwa: "Memotivasi dikatakan serangkaian untuk menyediakan kondisi-kondisi tertentu, sehingga seorang itu mau dan ingin melakukan sesuatu dan bila ia tidak suka, maka akan berusaha untuk meniadakan atau mengeluarkan perasaan tidak suka".

Handoko (1986:252) mengatakan bahwa "memotivasi diartikan sebagai keadaan dalam diri seseorang yang mendorong individu untuk melakukan kegiatan-kegiatan tertentu guna mencapai tujuan". Selanjutnya Sarwono (1993:57) mengartikan "memotivasi segala keseluruhan proses perbuatan atau tingkah laku manusia termasuk situasi yang mendorong, dorongan yang timbul dalam individu, tingkah yang ditimbulkan oleh situasi atau tujuan akhir dari perbuatan tersebut".

Dengan demikian bahwa memotivasi merupakan dorongan seseorang dalam mencapai suatu tujuan tertentu, baik dorongan yang datang dari dalam diri individu itu sendiri maupun dorongan yang datang dari luar individu itu. Sehingga keadaan memotivasi seseorang akan tampak dalam tingkah laku yang ditampakkan dalam mencapai sebuah tujuan.

Tujuan dalam penelitian ini adalah Mendeksripsikan motivasi orang tua dalam menyekolahkan anak pada keluarga petani secara intrinsik dan ekstrinsik di Jorong Dama Gadang Kenagarian Tanjung Sani Kecamatan Tanjung Raya Kabupaten Agam.

\section{METODE PENELITIAN}

Sesuai dengan tujuan penelitian ini yaitu motivasi orang tua dalam menyekolahkan anak pada keluarga petani secara intrinsik dan secara ekstrinsik di Jorong Dama Gadang Nagari Tanjung Sani Kecamatan Tanjung Raya Kabupaten Agam, maka jenis penelitian ini adalah penelitian kuantitatif dengan metode deskriptif yaitu metode yang harus menjabarkan mengenai apa yang akan kita teliti Arikunto dalam Retno (2009: 28).

Menurut Margono (1996: 105), penelitian kuantitatif adalah suaru proses menemukan pengetahuan yang menggunakan data berupa angka sebagai alat menemukan keterangan mengenai apa yang ingin kita ketahui.

Komariah dan Satori dalam Mawardi (1990: 29) menjelaskan bahwa mendeskripsikan sesuatu berarti menggambarkan apa, mengapa dan bagaimana suatu kejadian terjadi. Ibnu, dkk dalam Mawardi (1990: 29) mengatakan penelitian deskriptif bertujuan untuk mendeskripsikan (memaparkan) peristiwa yang terjadi pada masa kini. Penelitian ini tergolong penelitian deskrptif yang betujuan melihat gambaran atau keadaan subjek sebagaimana adanya. Menurut A. Muri Yusuf dalam Retno (2009: 28) penelitian deskriptif adalah salah satu penelitian yang bertujuan mendeskripsikan 


\section{Diklus: Jurnal Pendidikan Luar Sekolah, 1(3), Maret 2019 - 48 Rheny Guchi Erniati}

secara sistematis, aktual, dan akurat mengenai fakta dan sifat populasi tertentu dan menggambarkan fenomena secara detail.

Sesuai dengan masalah penelitian yang dirumuskan, maka yang menjadi populasi dalam penelitian ini adalah seluruh warga masyarakat yang ada di Jorong Dama Gadang Nagari Tanjung Sani Kecamatan Tanjung Raya Kabupaten Agam. Jumlah secara keseluruhan yang ada disana sebanyak 228 Kepala Keluarga, yang bekerja sebagai petani 95\% adalah $217 \mathrm{KK}$. Dan yang berhasil menyekolahkan anaknya sampai tamat SMA yaitu sebanyak 60\% adalah 130 orang. Dalam penelitian ini penulis mengambil sampel sebanyak $25 \%$ dari populasi maka jumlah sampelnya dalam penelitian ini adalah 33 orang.

Teknik pengumpulan data dalam penelitian ini adalah kuesioner (angket). Menurut Sugiyono (2008: 199), kuesioner merupakan teknik pengumpulan data yang dilakukan dengan cara memberi seperangkat pertanyaan atau pernyataan tertulis kepada responden untuk dijawabnya. Angket disusun dengan alternatif jawaban yaitu: Selalu (SL), Sering (SR), Kadang-Kadang (KK), dan Tidak Pernah (TP).

Teknik analisis data yang digunakan adalah persentase dimana setelah semua hasil jawaban responden terkumpul, maka langkah selanjutnya mentabulasi hasil jawaban responden.

Menghitung persentase jawaban responden dengan menggunakan rumus:

$$
P=\frac{f}{100} N \mathrm{X}
$$

Keterangan:

$\mathrm{P} \quad=$ Persentase yang akan diperoleh

$\mathrm{f} \quad=$ Frekwensi jawab dari masing-

masing Pertanyaan

$\mathrm{N} \quad=$ Jumlah sampel

\section{HASIL DAN PEMBAHASAN}

Gambaran Motivasi Orang Tua dalam Menyekolahkan Anak pada Keluarga Petani Secara Intrinsik

Untuk dapat melihat motivasi orang tua dalam menyekolahkan anak pada keluarga petani secara intrinsik dilakukan penyebaran kuisioner kepada 33 orang responden dengan 35 pertanyaan, diperoleh hasil jawaban masing-masing sesuai dengan apa yang dirasakan dan dialami oleh orang tua.

Dalam pengolahan data, setiap jawaban pada item yang digunakan diberi skor, butir untuk option Selalu/SL diberi skor 4 (empat), Sering/SR diberi skor 3 (tiga), Kadang-kadang/KK diberi skor 2 (dua), dan Tidak Pernah/TP diberi skor 1 (satu).:Jika digambarkan dengan histogram gambarannya sebagai berikut:

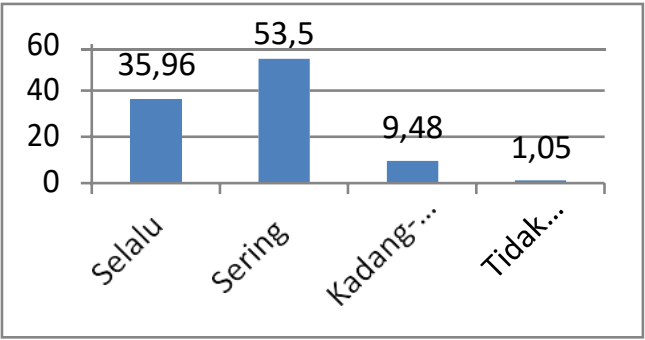

Gambar 1. Gambaran Motivasi Orang Tua dalam menyekolakan Anak pada Keluarga Petani Secara Inrinsik

Hasil penelitian menggambarkan tentang motivasi orang tua dalam menyekolahkan anak secara intrinsik pada keluarga petani di Jorong Dama Gadang Nagari Tanjung Sani Kecamatan Tanjung Raya Kabupaten Agam menunjukkan bahwa sebahagian besar orang tua menjawab pada alternatif selalu,sering, kadang-kadang dan tidak pernah adalah $35.96 \%, 53.50 \%, 9.48 \%$ dan $1.05 \%$.

Dengan demikian dapat disimpulkan bahwa menurut peneliti deskripsi data tentang motivasi orang tua 


\section{Diklus: Jurnal Pendidikan Luar Sekolah, 1(3), Maret 2019 - 49 Rheny Guchi Erniati}

dalam menyekolahkan anak secara intrinsik terlihat tinggi.

\section{Gambaran Motivasi Orang Tua dalam Menyekolahkan Anak pada Keluarga Petani Secara Ekstrinsik}

Untuk dapat melihat motivasi orang tua dalam menyekolahkan anak pada keluarga petani secara ekstrinsik dilakukan penyebaran kuisioner kepada 33 orang responden dengan 35 pertanyaan, diperoleh hasil jawaban masing-masing sesuai dengan apa yang dirasakan dan dialami oleh orang tua.

Dalam pengolahan data, setiap jawaban pada item yang digunakan diberi skor, butir untuk option Selalu/SL diberi skor 4 (empat), Sering/SR diberi skor 3 (tiga), Kadang-kadang/KK diberi skor 2 (dua), dan Tidak Pernah/TP diberi skor 1 (satu). Jika digambarkan dengan histogram gambarannya sebagai berikut:

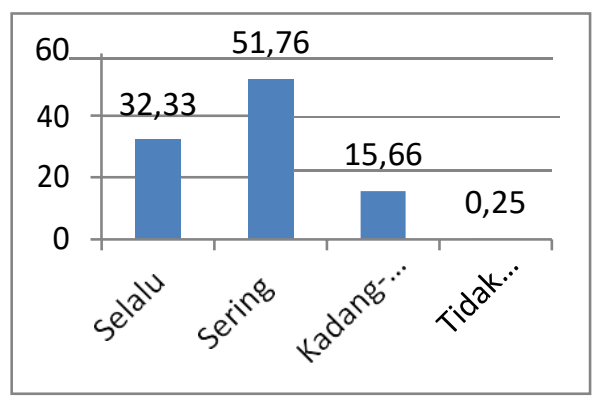

Gambar 2. Gambaran Motivasi Orang Tua dalam Menyekolahkan Anak pada Keluarga Petani Secara Ekstrinsik

Hasil penelitian menggambarkan tentang motivasi orang tua dalam menyekolahkan anak secara ekstrinsik pada keluarga petani di Jorong Dama Gadang Nagari Tanjung Sani Kecamatan Tanjung Raya Kabupaten Agam menunjukkan bahwa sebahagian besar orang tua menjawab pada alternatif selalu, sering, kadang-kadang dan tidak pernah adalah $32.33 \%, 51.76 \%, 15.66 \%$ dan $0.25 \%$.
Dengan demikian

dapat disimpulkan bahwa menurut peneliti deskripsi data tentang motivasi orang tua dalam menyekolahkan anak secara ekstrinsik terlihat tinggi.

\section{Pembahasan}

Motivasi orant tua adalah suatu usaha/ikhtiar yang dilakukan oleh seseorang yang memikul tanggung jawab sebagai ayah dan ibu dari anak-anaknya dalam mencapai suatu maksud untuk memecahkan persoalan dan mencari jalan keluar.

Handoko (1986:252) mengatakan bahwa "motivasi diartikan sebagai keadaan dalam diri seseorang yang dorongan individu untuk melakukan kegiatankegiatan tertentu guna mencapai tujuan". Selanjutnya Sarwono (1993:57) mengartikan "motivasi segala keseluruhan proses perbuatan atau tingkah laku manusia termasuk situasi yang mendorong, dorongan yang timbul dalam individu, tingkah yang ditimbulkan oleh situasi atau tujuan akhir dari perbuatan tersebut".

Motivasi yang dimaksud dalam penelitian ini adalah motivasi instrinsik yang berhubungan dengan pikiran, kemauan, perhatian, minat, kondisi berbuat, motivasi ekstrinsik yang berhubungan dengan nilai, hadiah, pujian dan sarana.

Berdasarkan hasil penelitian Motivasi Orang Tua dalam Menyekolahkan Anak pada Keluarga Petani di Jorong Dama Gadang Nagari Tanjung Sani Kecamatan Tanjung Raya Kabupaten Agam dalam meningkatkan pendidikan formal anak sudah terlihat baik. Untuk lebih jelas dapat dilihat pada uraian berikut ini.

\section{Gambaran Motivasi Orang Tua dalam Menyekolahkan Anak Secara Intrinsik}

Hasil penelitian menggambarkan tentang motivasi orang tua dalam menyekolahkan anak secara intrinsik pada keluarga petani di Jorong Dama Gadang 


\section{Diklus: Jurnal Pendidikan Luar Sekolah, 1(3), Maret 2019 - 50 \\ Rheny Guchi Erniati}

Nagari Tanjung Sani Kecamatan Tanjung

Raya Kabupaten Agam menunjukkan bahwa sebahagian besar orang tua menjawab pada alternatif selalu, sering, kadang-kadang dan tidak pernah adalah $35.96 \%, 53.50 \%, 9.48 \%$ dan $1.05 \%$.

Dengan demikian dapat

disimpulkan bahwa menurut peneliti deskripsi data tentang motivasi orang tua dalam menyekolahkan anak secara intrinsik pada keluarga petani di Jorong Dama Gadang Nagari Tanjung Sani Kecamatan Tanjung Sani Kecamatan Tanjung Raya Kabupaten Agam terlihat tinggi.

Motivasi instrinsik menurut Suryabrata dalam Retno (2009: 18) "motifmotif yang berfungsi bukan diakibatkan pengaruh rangsangan dari luar", sedangkan Purwanto (1990:65) yang dimaksud dengan motivasi secara instrinsik adalah "dorongan individu untuk bertindak adalah nilai-nilai yang terkandung dalam objek itu sendiri”. Sedangkan menurut Winkel (1984:28) mendefinisikan sebagai "bentuk motivasi yang didalamnya aktifitas belajar dimulai dan diteruskan berdasarkan suatu dorongan yang secara mutlak berkaitan dengan motivasi belajar".

Dengan melihat beberapa pendapat diatas, maka dapat disimpulkan bahwa indikator dari motivasi instrinsik adalah: Pemikiran, Kemauan, Perhatian, Minat dan kondisi berbuat.

Pikiran adalah sebuah representasi simbol dari beberapa peristiwa atau item Khodijah dalam Retno (2009: 21). Sedangkan menurut Drever dalam Waldito (1997:24) pikiran adalah melatih ide-ide dengan cara yang tepat dan seksama yang dimulai dengan adanya masalah. Solso dalam Waldito (1997:24) Pikiran adalah sebuah proses dimana representasi mental baru dibentuk melalui transformasi informasi dengan interaksi yang komplek atribut-atribut mental seperti penilaian, abstraksi, logika, imajinasi, dan pemecahan masalah.
Dari pengertian tersebut tampak bahwa ada tiga pandangan dasar tentang berpikir, yaitu (1) Pemikiran adalah kognitif, yaitu timbul secara internal dalam pikiran tetapi dapat diperkirakan dari perilaku, (2) berpikir merupakan sebuah proses yang melibatkan beberapa manipulasi pengetahuan dalam sistem kognitif, dan (3) berpikir diarahkan dan menghasilkan perilaku yang memecahkan masalah atau diarahkan pada solusi.

Kemauan adalah dorongan kehendak yang terarah pada tujuan-tujuan hidup tertentu, dan dikendalikan oleh pertimbangan akal budi. Jadi, pada kemauan itu ada kebijaksanaan akal dan wawasan, di samping itu juga ada kontrol dan persetujuan dari pusat kepribadian. Oleh kemauan, timbullah dinamika dan aktivitas manusia yang diarahkan pada pencapaian tujuan hidup tertentu.

Jadi, kemauan ini merupakan suatu usaha aktif karena adanya kebutuhan, dan usaha itu selalu didahului oleh kesadaran yang tergantung dan sesuai dengan segala kemungkinan yang ada pada diri masingmasing.

Menurut Dakir dalam Waldito (1997:26) Perhatian adalah keaktifan peningkatan kesadaran seluruh fungsi jiwa yang dikerahkan dalam pemusatannya kepada barang sesuatu baik yang ada di dalam maupun yang ada di luar individu. Sedangkan menurut Slameto dalam Retno (2009: 19) bahwa "perhatian juga dapat diartikan sebagai kegiatan yang dilakukan seseorang dalam hubungan nya dengan pemilihan rangsangan yang datang dari lingkungannya".

Dari beberapa pendapat di atas, dapat disimpulkan bahwa perhatian adalah pemusatan tenaga psikis yang tertuju pada suatu objek yang datang dari dalam dan dari luar individu.

Menurut Tidjan dalam Dyimyati (1982: 42) minat adalah gejala psikologis yang menunjukan pemusatan perhatian 


\section{Diklus: Jurnal Pendidikan Luar Sekolah, 1(3), Maret 2019 - 51 Rheny Guchi Erniati}

terhadap suatu obyek sebab ada perasaan senang. Sedangkan menurut Dyimyati (1999), Minat dalah sebagai sebab yaitu kekuatan pendorong yang memaksa seseorang menaruh perhatian pada orang situasi atau aktifitas tertentu dan bukan pada yang lain, atau minat sebagai akibat yaitu pengalaman efektif yang distimular oleh hadirnya seseorang atau sesuatu obyek, atau karena berpartisipasi dalam suatu aktifitas.

Berdasarkan beberapa pengertian minat menurut ahli tersebut penulis simpulkan bahwa minat adalah gejala psikologis yang menunjukan bahwa minat adanya pengertian subyek terhadap obyek yang menjadi sasaran karena obyek tersebut menarik perhatian dan menimbulkan perasaan senang sehingga cenderung kepada obyek tersebut.

Khodijah dalam Retno (2009: 21) bahwa "saat yang tepat untuk berbuat adalah ketika perbuatan yang kita lakukan adalah atas dasar ilmu". Anak sangat membutuhkan kasih sayang dan pujian orang tuanya. Salah satu hal yang bisa dikategorikan sebagai perwujudan rasa cinta dan penghormatan terhadap anak adalah dengan memujinya ketika melakukan perbuatan yang terpuji meskipun sedikit, memaafkan kesalahan yang ia lakukan, tidak menganggap bodoh kata-kata dan perbuatannya, dan tidak membebaninya pekerjaan yang diluar batas kemampuannya.

Jadi dapat disimpulkan perbuatan

yang dilakukan orang tua kepada anak dalam pendidikan adalah memberikan kasih sayang dan pujian serta memberi semangat kepada anak agar mereka termoivasi dalam melaksanakan pendidikan.

\section{Gambaran Motivasi orang tua dalam menyekolahkan anak Secara Ekstrinsik}

Hasil penelitian menggambarkan tentang motivasi orang tua dalam menyekolahkan anak secara ekstrinsik pada keluarga petani di Jorong Dama
Gadang Nagari Tanjung Sani Kecamatan Tanjung Raya Kabupaten Agam menunjukkan bahwa sebahagian besar orang tua menjawab pada alternatif selalu, sering, kadang-kadang dan tidak pernah adalah $32.33 \%, 51.76 \%, 15.66 \%$ dan $0.25 \%$.

Dengan demikian dapat disimpulkan bahwa menurut peneliti deskripsi data tentang motivasi orang tua dalam menyekolahkan anak secara ekstrinsik pada keluarga petani di Jorong Dama Gadang Nagari Tanjung Sani Kecamatan Tanjung Sani Kecamatan Tanjung Raya Kabupaten Agam terlihat tinggi.

Motivasi secara ekstrinsik menurut Sardiman: 22 motivasi ekstrinsik adalah "motif-motif yang aktif dan berfungsinya karena adanya rangsangan dari luar". Mudjiono dalam Dimyati (1999:91) mengungkapkan "motivasi ekstrinsik adalah dorongan perilaku seseorang yang ada di luar perbuatan yang dilakukannya. Orang berbuat sesuatu karena dorongan dari luar seperti adanya hadiah dan menghindari hukuman".

Bertitik tolak dari pendapat di atas maka penulis menyimpulkan indikator motivasi ekstrinsik adalah nilai, hadiah, pujian dan sarana.

Menurut Kimball dalam Retno (2009:

26) bahwa "nilai adalah asumsi yang abstrak dan sering tidak disadari tentang apa yang dianggap penting dalam masyarakat". Sedangkan menurut M.Z.Lawang Nilai adalah gambaran mengenai apa yang diinginkan, yang pantas, berharga, dan dapat memengaruhi perilaku sosial dari orang yang bernilai tersebut. (http://www.bangmu2.Com/2012/ 12/nilai- menurut-para-ahli.html).

Jadi dapat disimpulkan nilai adalah nilai adalah gambaran mengenai apa yang diinginkan yang pantas, berharga yang dapat memengaruhi perilaku sosial dari orang dan sering tidak disadari tentang apa yang dianggap penting dalam masyarakat. 


\section{Diklus: Jurnal Pendidikan Luar Sekolah, 1(3), Maret 2019 - 52 Rheny Guchi Erniati}

Menurut Purwanto (1995: 182) hadiah merupakan alat pendidikan represif yang menyenangkan, diberikan kepada anak yang memiliki prestasi tertentu dalam pendidikan, memiliki kemajuan dan tingkah laku yang baik sehingga dapat dijadikan teladan bagi teman - temannya.

Jadi dapat disimpulkan hadiah adalah alat pendidikan yang diberikan orangtua kepada anak untuk kemajuan dan tingkah laku yang baik bagi anak.

Pujian adalah menyatakan sesuatu yang positif tentang seseorang, dengan tulus dan sejujurnya. (http://id.wikipedia. org/wiki/Pujian). Pujian itu adalah sesuatu ucapan yang membuat orang yang mendengarnya merasa tersanjung, sehingga dapat juga memberikan motivasi kepada orang yang di puji.

Pujian itu penting sekali, guna untuk menunjukan betapa kita benar-benar menyukai apa yang di katakan, di lakukan, atau dicapai oleh seseorang. Pujian membuat orang menjadi lebih baik. Dan, kemampuan memuji adalah skill yang sangat berguna untuk dikuasai. Orang yang sering dipuji cepat atau lambat akan belajar untuk memuji orang lain juga.

Orang tua harus mengubah paradigma lama yang memandang bahwa guru yang menentukan segala-galanya, dengan paradigma baru yang memposisikan bahwa orang tua sebagai fasilitator yang bijaksana yang memfasilitasi sarana dan prasarana anak yang berhubungan dengan semua kebutuhan belajarnya dirumah, agar seorang anak dapat mengembangkan potensi dirinya baik sikap, pengetahuan, maupun keterampilan melalui pembelajaran yang aktif, kreatif, efektif, dan menyenangkan.

Jadi, poin-poin tersebut di atas harus dilakukan secara konsisten dan berulang-ulang hingga menjadi suatu kebiasaan dan menyatu dengan jiwa anak. Sehingga melalui pendekatan-pendekatan seperti itu, tujuan motivasi orang tua dapat terlaksana sebagaimana diharapkan akan tercapai secara optimal.

\section{SIMPULAN}

Berdasarkan hasil penelitian dan pembahasan dapat disimpulakan bahwa motivasi intrinsik orangtua dalam pendidikan pada keluarga petani di Jorong Dama Gadang Kenagarian Tanjung Sani Kecamatan Tanjung Raya Kabupaten Agam sebagian besar pada kategori baik sedangkan memotivasi ekstrinsik orantua sebagian besar juga termasuk pada kategori baik.

Saran yang dapat dikemukakan dalam penelitian ini adalah sebagai berikut: 1) Diharapkan kepada lembaga masyarakat yang terkait agar lebih memperhatikan pendidikan dalam keluarga petani tentang pendidikan luar sekolah melalui pola pendidikan keluarga.

2) Diharapkan kepada orang tua mampu memberikan pengetahuan tentang arti pentingnya pendidikan bagi anak, khusunya pada keluarga petani di Jorong Dama Gadang Kenagarian Tanjung Sani Kecamatan Tanjung Raya Kabupaten Agam. 3) Diharapkan kepada masyarakat tidak hanya memandang sebelah mata, yaitu bersikap acuh tak acuh terhadap keberadaan keluarga petani di Jorong Dama Gadang Kenagarian Tanjung Sani Kecamatan Tanjung Raya Kabupaten Agam. 4) Diharapkan kepada peneliti selanjutnya hasil penelitian ini dapat digunakan sebagai bahan bacaan dalam menambah wawasan peneliti.

\section{DAFTAR PUSTAKA}

Dimyati, dkk. (1999). Belajar Pembelajaran. Jakarta: Rineka Cipta.

Handoko. (1986). Psikologi Pendidikan. Bandung: Remaja Rosdakarya.

Hasbullah. (2001). Dasar-Dasar Ilmu Pendidikan. Jakarta: Raja Grafindo.

Koentjaraningrat. (1996). Pengantar Antropologi I. Jakarta: Rineka Cipta 


\section{Diklus: Jurnal Pendidikan Luar Sekolah, 1(3), Maret 2019 - 53 \\ Rheny Guchi Erniati}

Margono. (1996). Metodologi Penelitian Pendidikan. Semarang: Rineka Cipta.

Mawardi. (2001). Gaya Bahasa Kiasan Novel Rinai Kabut Singgalang Karya Muhammad Subhan dan Implikasinya Terhadap Pembelajaran Apresiasi Sastra. Skripsi. FBSS UNP. Padang

M.Z.Lawang .(2012).nilai-menurut-paraahli.http://www.bangmu2.Com/ 012/ 12/nilai- menurut-para ahli.html. (diakses 28 juni 2014)

Purwanto, M. Ngalim. (1990). Psikologi Pendidikan. Bandung: Remaja Rosdakarya

Retno. (2002). Deskripsi Kemampuan Menulis Puisi Siswa Kelas VIII Smpn 9 Payakumbuh Dengan Menggunakan Metode Objek Langsung Dan Media Gambar. Skripsi. FBSS UNP. Padang
Sarwono. (1993). Pengantar Umum Psikologi. Jakarta: Bulan Bintang

Sardiman, A.M. (2004). Interaksi dan Motivasi Belajar Mengajar. Jakarta: Raja Grafindo Persada.

Sugiyono. (2008). Metode Penelitian Kunatitatif Kualitatif dan $R \& D$. Bandung. Alfabeta

Undang-Undang RI Nomor 20 Tahun (2003). Sistem Pendidikan Nasional. Jakarta Depdikbud. (www. Google. com diakses pada tanggal 20 januari 2013)

Waldito, Putra. (1997): Deskripsi

Kemampuan Berfikir Siswa Kelas VIII Smpn 7

Bukittinggi Dengan Menggunakan Metode Objek Langsung Dan Media Gambar. FBSS. UNP. Padang

Winkel, Ws. (1984). Psikologi Pendidikan dan Evaluasi Belajar. Jakarta 